\title{
THROUGH THICK AND THIN: FROM THE REGULATION OF QUEERNESS TO QUEER THEORY AS DECOLONISATION
}

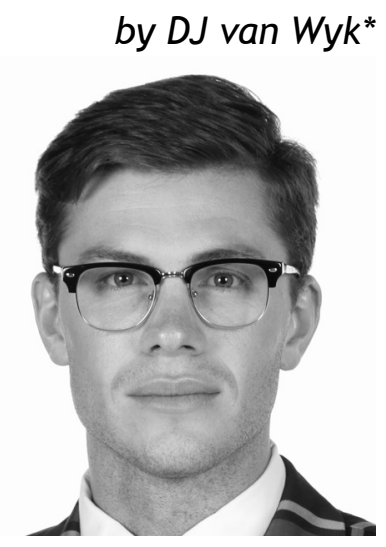

"African "homosexualities" can never be comfortably slotted within identity politics carved out of Western "gay" and "lesbian" liberation struggles, and display queer and even post-queer characteristics'.*

\section{Introduction}

The purpose of this essay is to investigate, criticise and recontextualise the concept of queerness in South Africa. I will do this by focusing on the historical regulation of queerness, the attempted transformation of queerness and the inevitable decolonisation of queerness. With the above established, and before proceeding, it is essential to understand the terminology that will be used in this essay. Queer is an alternative umbrella term 'which embraces a matrix of sexual preferences, orientations, and habits'. 1 Queer includes the same non-normative, sex-gender-sexuality identities as

* C Zabus 'Apartheid, queerness \& diaspora' in S Boydell \& J Brewer (eds) In out in Africa: Same-sex desire in sub-saharan literatures and cultures (2013) 188.

** LLB III (BSC), University of Pretoria. I would like to express my utmost gratitude and appreciation for Ms Zenia Pero (Academic Associate, Department of Jurisprudence) as she provided me with valuable academic advice, emotional support and motivation. I would also like to thank Nicholas Herd and Mex $M^{\prime}$ 'membe, who are two of the closest people in my life, for all the support they offered throughout this writing process

1 N Giffney “Introduction: The “q” word' in N Giffney (ed) The Ashgate companion to queer theory (2009) 2. 
LGBT-Q but it exceeds the limits of that term and further represents those who are gender non-conforming. ${ }^{2}$ The concept of queerness stems from this word and usually symbolises being against the norm or ab-normal. Whether this norm is heterosexuality or dominant gay identity - queerness goes against the norm and is seen as being definitively different. ${ }^{3}$

A brief inquiry into South Africa's history will show that sexuality and identity were rigorously regulated concepts during Apartheid. Homophobic laws, and the dominance of Christianity, resulted in the discrimination and marginalisation of queer people during the regime. ${ }^{4}$ After 1994, the Constitution of the Republic of South Africa (hereafter 'The Constitution') brought forward values of equality, freedom and human dignity that resulted in the prohibition of discrimination on the basis of sexual orientation. ${ }^{5}$ Additionally, legislative and judicial advances, such as the Civil Union Act 17 of 2006 (hereafter 'Civil Union Act') and the Minister of Home Affairs and Another $v$ Fourie and Another (hereafter 'Fourie') judgment ensured that same-sex partnerships were afforded a level of recognition and protection alongside the Marriage Act 25 of 1961 (hereafter 'Marriage Act'). ${ }^{6}$ These transformative mechanisms were accompanied by developments in queer theory and gender studies that questioned the nature of same-sex marriage and queer identity. In essence, queerness has faced many hardships and successes that must be critically investigated and analysed.

This critical investigation and analysis will be centred around three main questions regarding queerness: (1) How queerness has been regulated by western and apartheid concepts of social interaction?; (2) How queerness has been transformed in Post-1994 South Africa - specifically before and after the implementation of the Civil Union Act?; and (3) How can the current marriage systems - and queerness - be decolonised using queer theory? I will approach this essay using concepts of transformative constitutionalism, queer theory, and decolonial theory. By answering these three questions, I aim to prove that queerness (as a concept and identity) is something that requires sufficient decolonisation because it has been historically regulated, inaccurately defined and inadequately transformed. Furthermore, I will demonstrate how legal systems and knowledge, dealing with queerness, ought to be interrogated and altered to best represent queer people.

2 As above.

$3 \quad M$ van Zyl 'A sexual politics of belonging: Same-sex marriage in post-apartheid South Africa' PhD thesis, University of Stellenbosch, 2015 at 3.

$4 \mathrm{H}$ de Ru 'A historical perspective on the recognition of same-sex unions in South Africa' (2013) 19 Fundamina at 250.

$5 \mathrm{Sec} 9(3)$ of the Constitution of the Republic of South Africa 1996.

6 Minister of Home Affairs and Another v Fourie and Another 2006 (1) SA 524 (CC); De Ru (n 4) 250. 


\section{The regulation of queerness}

South Africa's constitutional history is plagued by two problematic systems: an institutionalisation of racism and a bias shown towards certain brands of Christianity. Using these two systems, the Apartheid government created a culture of state interference whereby the state would construct the identities, and regulate the private lives, of black and queer individuals. ${ }^{7}$ As a result of this, racist and biblical concepts of social interaction became institutionalised and they had a profound effect on queer people and social interactions in pre-1994 South Africa. ${ }^{8}$ The bias shown towards Christianity resulted in religiously influenced laws being passed that destroyed the sanctity of queer private lives that were seen 'strange' and 'not religiously normal'. '

Originally, it was seen as a common law offence when males engaged in sexual intimacy with each other (sodomy). At the same time, the Immorality Act prohibited 'any unnatural sexual acts' in general and regarded same-sex relations as unnatural, criminal and deviant. ${ }^{10}$ Further apartheid legislation, such as the Sexual Offences Act, criminalised any sexual acts between males that intended to bring about sexual pleasure. ${ }^{11}$ This form of 'naked hatred' towards queer people was a violent limitation of their freedoms and choices to partake in intimacy and relations with one another. ${ }^{12}$ Queer people across the spectrum were classified as criminals and perverts and thus, socially excluded and marginalised by broader South African society. ${ }^{13}$ This was the beginning of legally constructed differences between heterosexuals and homosexuals, whereby the government would socially construct sexuality into something detestable. ${ }^{14}$

With regards to same-sex marriage, the traditional concept of marriage is still seen as: 'a voluntary union for life between one man and one woman to the exclusion of others while it lasts'. ${ }^{15}$ This concept emanated from religious western countries such as Holland and England and it formed part of their marriage laws (Roman-Dutch Law and Common Law). ${ }^{16} \mathrm{~A}$ deeper analysis of this concept will show

7 De Ru (n 4) 225

8 P De Vos \& J Barnard 'Same-sex marriage, civil unions and domestic partnerships in South Africa: critical reflections on an ongoing saga' (2007) 124 South African Law Journal at 796.

9 J Barnard 'Totalitarianism, (same-sex) marriage and democratic politics in post1994 South Africa' (2007) 23 South African Journal of Human Rights at 501.

10 De Vos \& Barnard (n8) 797; Immorality Act 21 of 1950.

11 Sec 20A Sexual Offences Act 23 of 1957.

12 De Vos \& Barnard (n8) 797.

13 National Coalition for Gay and Lesbian Equality v Minister of Justice 1999 (1) SA 6 (CC) paras 27-28.

$14 \mathrm{~K}$ van Marle \& $\mathrm{E}$ Bonthuys 'Feminist theories and concepts' in C Albertyn \& E Bonthuys (eds) Gender, Law and Justice (2007) at 25.

15 De Ru (n4) 221; Ismail v Ismail 1983 (1) SA 1006 (A).

16 H Hahlo \& E Kahn The South African legal system and its background (1968) 511. 
that Euro-Western societies incorporated Christian-centred principles of anti-divorce ('for life'), heterosexuality ('one man and one woman') and monogamy ('to the exclusion of others') into their fundamental ideals of marriage. ${ }^{17}$ These Euro-Western ideals above were brought to Africa by the European colonisers and they were implanted into some African societies that already supported and practiced forms of homosexual marriage, polygynous marriage, and the pursuance of intimacy outside of formal relationships. ${ }^{18}$ However, there were African cultures that did not accept and support homosexuality in any form and the implantation of Euro-Western Christianity reinforced the already dominant cultural narrative that existed. ${ }^{19}$ Essentially, the principles of a Christian-marriage and the imposition of colonialism caused heterosexual-monogamy to be the generally 'enforced' marriage system in South Africa. ${ }^{20}$ Furthermore, these principles were used to construct gender, race and sexuality in such a way that marginalised individuals lost their own sense of self. An example of this is the way in which sexuality was constructed to exclude diverse same-sex practices in African cultures. ${ }^{21}$

A further aggravating factor was that courts did not have the ability to question any of these laws or regulations due to parliamentary sovereignty. ${ }^{22}$ Thus, queer people were left with very few defences as the courts had to implement homophobic legislation formalistically, and not question it. ${ }^{23}$ These political and judicial practices fixed sexuality onto an individual person and they showed a blatant disregard for human connection and morality. ${ }^{24}$ Traditional, legal and scientific discussions about sexuality focused purely on procreation between two heterosexual partners and they failed to recognise that queer identities and interactions existed within sexuality. This systemic failure to recognise a group of people, due to their identity, is one of the main points of regulation and suppression faced by queer people. ${ }^{25}$ Objectively, queerness was being regulated through governmentally-enforced laws that were extremely oppressive and homophobic in nature. Furthermore, it can be argued that homophobia was colonially constructed and implanted into communities that previously had no problem with homosexuality because this would secure the hegemony the government had. ${ }^{26}$

17 H Hahlo The South African Law of Husband and Wife (1985) 21.

18 B Dlamini 'Homosexuality in the African Context' (2006) 67 Agenda: Empowering Women for Gender Equality at 130-132; Hahlo (n17) 14.

19 Dlamini (n18) 133-134.

20 Van Zyl (n3) 7.

21 E Bonthuys 'Race and gender in the Civil Union Act' (2007) 23 South African Journal of Human Rights at 541.

22 W Hosten et al Introduction to South African law and legal theory (1995) 337.

$23 \mathrm{~J}$ Robinson "The evolution of the concept of marriage in South Africa: the influence of the evil of rights in 1994' (2005) 26 Obiter at 489.

24 Van Zyl (n 3) 7.

25 Van Zyl (n 3) 7.

26 Van Zyl (n 3) 8. 
The totalitarianism of the apartheid regime was so rigorous that no queer rights movements took place before the 1980s. ${ }^{27}$ All gay liberation movements were met with elements of force and suppression because they were seen as directly challenging the apartheid government. However, during the 1980s and 1990s, many different movements and organisations were established that focused on the advancement and protection of queer people. ${ }^{28}$ These movements would form alliances with racial and feminist antiApartheid movements because they argued that their oppression stemmed from the same source - the Apartheid government. ${ }^{29}$ Internal tensions emerged in these organisations because queer members couldn't decide between offering support or advancing activism. These internal tensions hindered the queer movements because many members felt that they were being regulated and suppressed by other queer bodies in the movements. This form of internal regulation of queerness was additional to the external regulation of queerness enforced by the government. Racial and gender divides were also contributing factors to the internal regulation of queerness that occurred throughout the community. ${ }^{30}$ White gay men experienced significant amounts of preferential treatment when compared to black gay men and lesbian women. An example of this was that black gay men were prevented from accessing the same bars and gatherings as white gay men because of racial segregation that took place during apartheid. ${ }^{31}$ Furthermore, white conservative queer people did not want to identify with any form of political struggle or movement because they were comfortable in the 'bar-cruising' lifestyle that they found themselves in. ${ }^{32}$ Pierre De Vos argues that the reluctance by white queer people to join movements and foster inclusivity was a strategy used to uphold a standard of white 'purity' and 'class' that they also ascribed to. ${ }^{33}$ This shows that black and female queerness faced regulation from all societal fronts - including their own community of queer people.

The internal and external regulation of queerness was difficult to overcome during apartheid and it hindered the advancement of queer issues and identities in South Africa. ${ }^{34}$ The fall of Apartheid brought forward a new era established under a Constitution that enshrined principles of equality, freedom and human dignity. ${ }^{35}$ The legal

27 Barnard (n 9) 501.

28 J Cock 'Engendering gay and lesbian rights: The equality clause in the South African Constitution' (2002) 26 Woman's Studies International Forum at 37.

29 De Ru (n 4) 222.

30 Van Zyl (n 3) 9-10.

31 Van Zyl (n 3) 9.

32 Van Zyl (n 3) 10.

33 De Vos \& Barnard (n 8) 798.

34 M Nell \& J Shapiro 'Out of the box: Queer youth in South Africa' (2011) 16 The Atlantic Philanthropies at 12.

35 Secs 9-10 of the Constitution; De Ru (n 4) 250. 
recognition and equality given to queer people meant that they could challenge religious and ideological systems that previously oppressed them. ${ }^{36}$ Thus, a movement towards transforming and decolonising institutions and concepts began.

\section{The transformation of queerness}

\subsection{Transformative constitutionalism - Section 9(3)}

Oppression, inequality and hatred are characteristics that can be used to define the apartheid regime. Thus, after the fall of apartheid, South Africa needed large-scale social, legal and political transformation. ${ }^{37}$ The post-1994 Constitution was adopted to give effect to this transformative goal and change society. ${ }^{38}$ Additionally, the concept of transformative constitutionalism emanated from the Constitution and it can be defined as:

a long-term project of constitutional enactment, interpretation, and enforcement committed to transforming a country's political and social institutions and power relationships in a democratic, participatory, and egalitarian direction. ${ }^{39}$

One of the biggest contributing factors towards transformation was, and still is, section 9 of the Constitution. The inclusion of sexual orientation in section $9(3)$ resulted in discrimination, on the grounds of sexual orientation, being prohibited. ${ }^{40}$ This meant that any discriminatory and oppressive statutes, aimed at queer people, could now be declared unconstitutional. ${ }^{41}$ Moreover, queer organisations strategically used section $9(3)$ to gain additional rights and this ensured that social transformation could take place in a non-violent manner that upheld the values of transformative constitutionalism. ${ }^{42}$ Ultimately, queer individuals were able to attain a sense of peace and justice using this transformative provision. It signalled the end of queer repression, and the beginning of queer inclusion. ${ }^{43}$ The only problem was that - the Constitution was only a protective and equitable mechanism for marginalised individuals. The Constitution never advanced or called for the deconstruction of harmful colonial constructs surrounding race, gender and sexuality.

36 De Ru (n 4) 222.

37 K Klare 'Legal culture and transformative constitutionalism' (1998) 14 South African Journal on Human Rights at 150.

38 Preamble of the Constitution of the Republic of South Africa 1996.

39 Klare (n 37) 150.

40 De Ru (n 4) 250.

41 Bonthuys (n 21) 528.

42 Klare (n 37) 150.

$43 \mathrm{~V}$ Reddy 'Decriminalisation of homosexuality in post-Apartheid South Africa: A brief legal case review from sodomy to marriage' (2006) 67 Agenda: Empowering Women for Gender Equity at 148. 
Transformative adjudication and transformative law making were mechanisms used to facilitate the decriminalisation of queer identity. Transformative judgments that brought an end to unconstitutional laws and transformative statutes that legalised previously illegal interactions formed part of Karl Klare's definition of transformative constitutionalism ('constitutional interpretation and enactment'). ${ }^{44}$ The transformation of social and legal perspectives surrounding queerness resulted in the recognition, and expression, of queer individuals who had never had the opportunity to do so during apartheid. ${ }^{45}$ Queer people now occupied a space in South African society and many judgments reflected this in landmark rulings.

\subsection{Transformative adjudication - pro-queer litigation}

Apartheid legal culture practiced a form of restricted jurisprudence that can be described as formalistic and positivist in nature. ${ }^{46}$ This approach persisted throughout because parliamentary sovereignty supported a positivist legal theory of law. This meant that judges had to strictly and simply apply homophobic and oppressive laws made by political superiors. ${ }^{47}$ The post-1994 Constitution changed this by incorporating values and principles that needed to be considered in all legal matters. A constitutional interpretation can be described as practicing general jurisprudence as it aims to harmonise legal interpretation with substantive societal goals. ${ }^{48}$ The National Coalition for Gay and Lesbian Equality $v$ Minister of Justice is an example of this form of jurisprudence because the court held that the common law offence of sodomy violated queer men's rights to dignity and equality. ${ }^{49}$ When making this decision, the Court considered the historical oppression that queer men faced and furthermore, the court advanced the concept of transformative constitutionalism to ensure that queer identity was protected. ${ }^{50}$

In the Minister of Home Affairs $v$ Fourie case, the Marriage Act, which codified the common-law definition of marriage, was constitutionally challenged. ${ }^{51}$ The Constitutional Court held that the common law definition was inconsistent with the Constitution and furthermore, section 30(1) was declared invalid because it prevented same-sex couples from accessing the same status and benefits as heterosexual couples. ${ }^{52}$ Sachs $\mathrm{J}$ stated the following:

44 Klare (n 37) 150; Reddy (n 43) 146.

45 As above.

46 C Douzinas \& A Gearey Critical jurisprudence:The political philosophy of justice (2005) 6.

47 A van Blerk Jurisprudence: An introduction (1998) 29.

48 Klare (n 37) 188; Douzinas \& Gearey (n46) 10.

49 National Coalition for Gay and Lesbian Equality (n 13) para 62.

50 Reddy (n 43) 149.

51 Fourie (n 6) para 67.

52 De Vos \& Barnard (n 8) 824; Fourie (n 6) para 67. 
the exclusion of same-sex couples from the benefits and responsibilities of marriage is not a small and tangential inconvenience ... It represents a harsh statement by the law that same-sex couples are outsiders, and that their need for affirmation and protection ... is somehow less than that of heterosexual couples. ${ }^{53}$

In the above statement, Sachs $J$ demonstrates a general jurisprudential approach to interpretation that incorporates morality and values. ${ }^{54}$ This approach is fundamental to transformative adjudication because its successful application will result in equitable outcomes which are necessary for transformation in society. ${ }^{55}$ Etienne Mureinik stated that South African law has to develop into a culture of justification that is self-conscious and reflective. He argues that: values, principles and texts need to be analysed to produce the most reasoned justification for legal matters. ${ }^{56}$ The Fourie case is an example of this.

Moreover, various courts have consistently upheld the principles of human dignity, equality and freedom when dealing with same-sex relationships. In many pro-queer cases, the courts have played a role in further transforming the lives of queer people. ${ }^{57}$ Examples of this include; giving queer couples the ability to adopt children, allowing same-sex life partners the ability to claim damages from the Road Accident Fund, and giving same-sex life partners a claim to maintenance if they are financially dependent. ${ }^{58}$ Essentially, rights and privileges are being extended to queer individuals on a public platform. Thus, queer identity was given the opportunity to develop and gain awareness but in a violent fashion because of resistance by the state and backlash from the public. ${ }^{59}$

The Constitution can be defined as a document of historical selfconsciousness and transformation. ${ }^{60}$ With that said, the Constitutional Court has regularly emphasised that the progressive effect of transformative adjudication cannot be limited to interpretation alone. ${ }^{61}$ Thus, in the Fourie case, the court went a step further and ruled that parliament must enact legislation that remedies the constitutional issues outlined in the case. ${ }^{62}$

53 Fourie (n 6) para 78

54 Douzinas \& Gearey (n 46) 10.

55 Klare (n 37) 163.

56 E Mureinik 'A bridge to where? Introducing the Interim Bill of Rights,' (1994) 10 South Afrcian Journal of Human Rights at 31-32; Klare (n37) 147.

57 De Vos \& Barnard (n8) 800.

58 Du Toit and Another $v$ Minister of Welfare and Population Development and Others 2003 (2) SA 198 (CC); Du Plessis v Road Accident Fund 2004 (1) SA 359 (SCA); Langemaat $v$ Minister of Safety and Security 1998 (3) SA 312 (T).

59 Reddy (n43) 150-151.

60 Klare (n 37) 155.

61 Klare (n 37) 150; De Vos \& Barnard (n 8) 801.

62 Fourie (n 6) para 80. 


\subsection{Transformative law making - the Civil Union Act}

Before 2006, same-sex marriage was not recognised in South African law because it fell outside the scope of religious, statutory and common-law principles of marriage. ${ }^{63}$ The Marriage Act was the only statute regulating marriage in South African family law until 2000. The Recognition of Customary Marriages Act was then enacted and it regulated customary marriages in South Africa. ${ }^{64}$ However, these civil and customary marriage systems only recognised, and protected, heterosexual marriages. Many members of the queer community challenged this perception because it was a form of social exclusion and inequality that resembled the treatment of queer people during Apartheid. ${ }^{65}$ The Fourie case was a fundamental actor in addressing this and was a catalyst for future same-sex marriage legislation. In this case, the Constitutional Court demonstrated a willingness to advance cultural politics and uphold the notion of multiculturalism and diversity. ${ }^{66}$ Requiring parliament to enact same-sex marriage legislation can be seen as a step towards national reconciliation and furthermore, it promotes the realisation of justice and rights for vulnerable identity groups. ${ }^{67}$

In 2006, the African National Congress tabled the Civil Union Bill in Parliament. ${ }^{68}$ The majority party had to comply with the ruling in the Fourie case even though the majority of their supporters opposed the Bill. After many debates and opportunities for public participation, parliament enacted the Civil Union Act which permitted anyone - both heterosexuals and homosexuals - to conclude a monogamous marriage in terms of the Act. ${ }^{69}$ The Preamble to the Civil Union Act recognises that South African family law failed 'to provide for same-sex couples to enjoy the same status and benefits ... as heterosexual couples'. ${ }^{70}$ Section 1 of the Act defines a civil union as:

the voluntary union of two persons who are both 18 years or older, which is solemnised and registered by way of either a marriage or a civil partnership, in accordance with the procedures prescribed in this Act, to the exclusion, while it lasts, of all others. ${ }^{71}$

63 J Sinclair \& J Heaton The Law of Marriage (1996) 305; Reddy (n 43) 152.

64 Recognition of Customary Marriages Act 120 of 1998; De Vos \& Barnard (n 8) 824.

65 Reddy (n 43) 153.

66 Klare (n 37) 155.

67 As above.

68 Parliamentary Monitoring Group Committee Report, https://pmg.org.za/commi ttee-meeting/7587/ (accessed 26 May 2019).

69 B Goldblatt 'Same-sex marriage in South Africa: The Constitutional Court's judgment' (2006) 14 Feminist Legal Studies at 261.

70 Preamble of the Civil Union Act 17 of 2006.

71 Sec 1 of the Civil Union Act 17 of 2006. 
Section 13(1) of the Act states that the legal consequences found in the Marriage Act, must apply to civil unions concluded in terms of the Civil Union Act. ${ }^{72}$ Thus, the preamble and the above-mentioned provisions demonstrate that the Act intended to achieve three things: (1) to extend formal rights to queer couples; (2) to add substantive rights that equalised the social meaning of marriage; and (3) to transform the centralised concept of marriage. ${ }^{73}$

Enacting legislation forms part of the legalisation campaign that ensures the allocation of rights to queer individuals. ${ }^{74}$ It is evident that same-sex marriage legislation embodies the idea of social transformation envisaged by the Constitution. The legislation questions traditional views regarding marriage and it transforms queerness into a legally accepted and recognised construct. ${ }^{75}$ This results in an emphatic transformation of social interaction because recognition, protection and inclusion are advanced in broader society. ${ }^{76}$ Thus, the Constitutional goal of social transformation is achieved, to some extent, using transformative law making.

\subsection{Criticisms regarding the transformative approaches}

Questions arise when these transformative mechanisms are deeply analysed using the Constitution. One question is: have these transformative approaches achieved political freedom and socioeconomic justice for queer people? ${ }^{77}$ Second, has queerness been transformed and deconstructed to such an extent that queer people are able to freely exist and express themselves? I put forward a criticism that says no.

Section 6 of the Civil Union Act answers both of the questions in the negative. Section 6 gives state individuals the power to refuse solemnising homosexual civil unions based on religion, conscience and belief. ${ }^{78}$ Thus, any state officials can rely on of these grounds, which inform their personal belief systems and prevent the actualisation of rights afforded to same-sex couples. The ability to discriminate against same-sex couples reinforces the idea that same-sex couples are constructed as 'inferior' and 'unwanted'. ${ }^{79}$ Thus, queerness is not

72 Sec 13 of the Civil Union Act 17 of 2006.

73 D Bilchitz \& M Judge 'For whom does the bell toll? The challenges and possibilities of the Civil Union Act for family law' (2007) 23 South African Journal of Human Rights at 484.

74 Reddy (n 43) 155.

75 Van Zyl (n 3) 8

76 Reddy (n 43) 155.

77 Klare (n 37) 154.

78 Sec 6 of the Civil Union Act 17 of 2006.

79 Daily Maverick, P De Vos \& J Barnard-Naude 'Legislation still not recognising problem of "separate but equal" same-sex marriage' 30 November $2018 \mathrm{https}$ :// www.dailymaverick.co.za/article/2018-11-30-legislation-still-not-recognisingproblem-of-separate-but-equal-same-sex-marriage/ (accessed 16 May 2019). 
actually transformed by the Civil Union Act because section 6 leaves queer people open to discrimination from a heteronormative state. ${ }^{80}$ A legislative solution has been brought forward in the form of an Amendment Bill which was tabled in 2018. This Bill has been passed in the National Assembly (and will be going to the National Council of Provinces), and its purpose is to repeal the controversial section from the Act. ${ }^{81}$ Thus, an effort has been shown to cure the unconstitutionality of the Act and advance the movement towards recognition and protection for queer bodies.

With that said and the abovementioned being progressive on paper, two problems still exist with regards to the proposed Amendment Bill. The first problem is that the Amendment Bill delays the implementation of the amendment by 24 months. ${ }^{82}$ The transitional period has been put in place so that the Department of Home Affairs has sufficient time to train and educate the current marriage officers who have readily relied on section 6 of the Act. ${ }^{83}$ This transitional period is problematic in the sense that it keeps the section operational for another 24 months and allows for marriage officials to carry on discriminating against queer bodies who want to get their unions solemnised. Furthermore, this becomes practically questionable because the procedures currently used for solemnising heterosexual marriages should be exactly the same as the procedures that will be implemented for solemnising homosexual unions. Thus, why the need for this 24 -month training period? ${ }^{84}$ The second problem is that no effort has been shown to deconstruct the western constructs around gender and sexuality. What I mean by this is that this Amendment Bill does not do enough to change the current Marriage Act, or better yet, do away with the Civil Union Act and instead have one piece of legislation that regulates marriages and unions across the spectrum. De Ru argues that the notion of 'separate but equal' is utilised to reinforce the desired constructs and hegemony of the state. ${ }^{85}$ The Civil Union Act relegates same-sex marriage to a second-class status and it creates further marginalisation and oppression for queer people. ${ }^{86}$ Thus, the Amendment Bill should not have simply targeted one section but rather, it should have targeted the entire Act and other Acts that it is in proximity to.

80 As above.

81 Section 1 of the Civil Union Amendment Bill B11-2018.

82 Section 2 of the Civil Union Amendment Bill B11-2018.

83 As above.

84 Daily Maverick (n 79) https://www.dailymaverick.co.za/article/2018-11-30-legis lation-still-not-recognising-problem-of-separate-but-equal-same-sex-marriage/.

85 De Ru (n 4) 248.

86 As above. 
With that established, my critical focus will shift to the Marriage Act and its constitutionality. ${ }^{87}$ To a large extent, there are no significant differences between the Civil Union Act and the Marriage Act. Rights and obligations were almost identical in both Acts thus, the Civil Union Act never altered the gender and sexuality constructs imposed by the Marriage Act. ${ }^{88}$ The only clear difference is the fact that heterosexual couples can choose to get married in terms of the Marriage Act and Civil Union Act, whereas homosexual couples can only get married in terms of the Civil Union Act. This distinction creates a superiority complex in heterosexual couples because they are given an extra choice regarding marriage. This extra choice means that they can choose to exclude themselves from 'unwanted' homosexual couples who use the Civil Union Act. ${ }^{89}$ The existence of such inequality proves that the Marriage Act has questionable constitutionality and decolonial outlooks. Even after the Fourie case, the codified common-law definition remained in the Marriage Act. ${ }^{90}$ Thus, I submit that the only constitutional options for the transformation and decolonisation of queerness are: (1) opening the Marriage Act to same-sex partners or (2) repealing the Marriage Act, Civil Union Act and Recognition of Customary Marriages Act and enacting a single marriage statute for all marriages. ${ }^{91}$ The second option is also purported by the South African Law Reform Commission (SALRC) in Issue Paper 35 which details project $144 .{ }^{92}$ This project focuses on the idea of a single marriage statute and in it, the SALRC outlines the quest for a unified and uniform marriage legislation. ${ }^{93}$ The Issue Paper contains two clear positions regarding the subject of a single marriage statute. The first is:

The SALRC noted that South Africa's new Constitution provided the opportunity to make a break with the past and to send a clear message that discrimination would no longer be tolerated. The SALRC was of the view that that message had to be reflected in the principle of a single marriage law which would apply equally to all South Africans. ${ }^{94}$

The second is:

A single marriage statute can take two different forms - either a unified set of requirements (and possibly consequences) applying to all marriages or alternatively a single act which contains different chapters

Daily Maverick (n 79) https://www.dailymaverick.co.za/article/2018-11-30-legis lation-still-not-recognising-problem-of-separate-but-equal-same-sex-marriage/.

88 E Bonthuys 'Irrational accommodation: conscience, religion and same-sex marriage in South Africa' (2008) 125 South African Law Journal at 477.

89 De Vos \& Barnard (n 8) 821.

90 As above.

91 Daily Maverick (n 79) https://www.dailymaverick.co.za/article/2018-11-30-legis lation-still-not-recognising-problem-of-separate-but-equal-same-sex-marriage/

92 South African Law Reform Commission Issue Paper 35 'Project 144: Single Marriage Statute' (2019).

93 South African Law Reform Commission Issue Paper 35 (n 92) 5-6.

94 South African Law Reform Commission Issue Paper 35 (n 92) 6. 
which reflect the current diverse set of legal requirements for and consequences of civil marriages, civil unions, customary marriages, Muslim and possibly other religious marriages...The academic consensus seems to be in favour of the creation of a single basic statute to govern different cultural, religious and secular marriages rather than retaining the current piecemeal situation. ${ }^{95}$

Transforming South Africa and removing the stains of apartheid can be a long and tedious process. The Constitution is an instrument available to citizens and legal practitioners and it can be used to successfully complete this process. ${ }^{96}$ However, to achieve sufficient transformation, we cannot be hesitant or selective when deconstructing the problematic notions around sexuality and gender. The decision to separate homosexuals from heterosexuals meant that they were not worthy of integration and consideration. ${ }^{97}$ This has exposed South Africa as a country that narrowly defines freedom and human existence. Furthermore, it shows that queer problems and problems of equity remain unresolved. ${ }^{98}$ The Civil Union Act was an extremely progressive step for South Africa - but the implementation never questioned the colonial construct of sexuality and gender. Thus, it was ineffective in decolonising queerness and ensuring that queer identities were developed.

\section{The decolonisation of queerness}

The current, post-colonial, approach used to attain queer liberation is transformative in nature. The Civil Union Act is one mechanism being used to transform marriage systems and queerness in South Africa. However, the identifiable problem is the fact that it is not queer or decolonial in nature. True liberation and transformation can only be achieved if queerness is decolonised and moved away from the colonial constructs that regulate it today. ${ }^{99}$ A disassociation from, and a deconstruction of, western norms is needed for decolonisation to take place. As outlined above, the transformative Civil Union Act makes detrimental concessions to colonialism thus, it merely advances rights at the expense of queer identities. ${ }^{100}$ In this section, I will highlight the three theories that can be used to adequately decolonise queerness and ensure the removal of social constructs that limit queer identity.

95 South African Law Reform Commission Issue Paper 35 (n 92) 15.

96 Klare (n 37) 155.

97 J Landau 'Marriage as integration' in A Sullivan Same-sex marriage pro \& con - A reader (2004) at 319.

98 A Mbembe 'At the centre of the knot' (2012) 38 Social Dynamics at 12.

99 De Vos \& Barnard (n 8) 821.

100 C Douzinas 'Human rights and post-modern utopia' (2000) 11 Law and Critique at 232. 


\subsection{Queer, decolonial and feminist theories}

'Queer' is not just an umbrella term for the LGBT-Q community - it is a term that allows you to think differently about your identity and surroundings. ${ }^{101}$ It is characterised as a form of resistance and celebration that seeks to disturb identities, not define them. By doing so, it represents anyone that rejects the 'white heterosexual middle class' norm and stereotype. ${ }^{102}$ Noreen Giffney maintains that the term 'queer' recognises identity as socially constructed thus, it emphasises self-reflection and fluidity to overcome this. She further argues that, queerness is essentially the 'disidentification' from categories perpetuated by religious and government institutions. ${ }^{103}$ Queer theory stems from the concept of queerness and it is a mode of thinking that questions the positionality of queerness in society. ${ }^{104}$ It is an analytical tool that interrogates the historical and modern codes of behaviour that seek to regulate queerness. In essence, it aims to critique the previous methods used to conceptualise identity. ${ }^{105}$ What queer theory aims to do is question the fixed, and stable, identitycategories that exist in society. Furthermore, it is aimed at breaking down the perpetuation of categories that cause significant harm to those in marginalised positions. ${ }^{106}$ Thus, queer theory is both a theoretical, and practical, mechanism that questions identity beyond what is socially constructed as identity. ${ }^{107}$

Queer theory intersects with the goals of decoloniality in many ways. Both theories question the structure of identity and problematise the incorporation of colonial constructs. ${ }^{108}$ The need to decolonise is urgent because African and queer identities have been restricted to such an extent that they no longer resemble what they once were, or what they could be. African and queer individuals are overwhelmed with western religions and norms and this fundamentally diminishes their ability to construct unique individual identities. ${ }^{109}$ Decolonial theory seeks to eliminate concepts that emanated from colonial sources and furthermore, it seeks to remove

101 Giffney (n 1) 1.

102 The Conversation, TL McCormick 'Why same-sex marriage is not the ultimate tool for queer liberation' 14 October 2018 https://theconversation.com/why-samesex-marriage-is-not-the-ultimate-tool-for-queer-liberation-103702 (accessed 26 May 2019).

103 Giffney (n 1) 3.

104 TL Mccormick (n 102) https://theconversation.com/why-same-sex-marriage-isnot-the-ultimate-tool-for-queer-liberation-103702.

105 K Watson 'Queer Theory' (2005) 38 Group Analysis at 68, 67-81; Giffney (n 1 ) 4.

$106 \mathrm{~J}$ Gedro \& R Mizzi 'Feminist theory and queer theory: Implications for HRD research and practice' (2014) 16 Advances in Developing Human Resources at 450.

107 Giffney (n 1) 5.

$108 \mathrm{~K}$ Wiredu 'Conceptual decolonisation as an imperative in contemporary African philosophy: Some personal reflections' (2002) 36 Rue Descartes at 54.

109 SJ Ndlovu-Gatsheni 'Decoloniality as the future of Africa' (2015) 13 History Compass at 488, 485-496; Wiredu (n 108) 55. 
colonial presumptions from the minds of those who were once colonised. ${ }^{110}$ It critiques Eurocentric methods that were used to conceptualise identity and reinforce the idea of universalism. ${ }^{111}$ Wiredu and Serequeberhan believe that African societies overvalue what comes from the west thus, a generic western identity is perpetuated, sustained and conserved. ${ }^{\$ 12}$ I support the belief that individuals must dissociate themselves from coloniality and rationally focus on deconstructing the identities that have been imposed on them. By doing so, individuals will be able to self-reflect and decolonise knowledge, being and power that has limited their identity and sense of self. ${ }^{113}$ This intersects with queer theory in that, queer theory also focuses on removing the colonial constructs surrounding sexuality and challenging the universalist notion of queerness.

Moreover, decolonial and queer theories cannot ignore the influence and intersection of feminist theory. Feminist theory goes as far as challenging the notion that: 'man is a natural category, and woman exists only in relation to man'. ${ }^{114}$ Van Marle maintains that social context influences the way in which a person experiences their gender and sexual orientation. Thus, their experiences are products of socialisation and not their actual gender and sexual identities. ${ }^{115}$ This position clashes directly with the colonial position that gender and sexuality are social constructs. Hence, it is evident that feminist theory works against the dominant constructs and concepts in society. ${ }^{116}$ Additionally, this theory embodies the same disruptive and self-reflective spirit as queer and decolonial theory. ${ }^{117}$ Feminist and queer theories don't just sporadically intersect; they constantly intertwine and advance the same ideas. A separation of the two will slowly result in negative outcomes such as a lack of inclusion and societal change. Both theories interrogate sexuality and gender at an individual level, organisational level, and societal level. ${ }^{118}$ Essentially, it can be concluded that feminist theory creates an environment in which queer theory can thrive.

\subsection{Decolonial criticisms of the Civil Union Act}

As established above, the Civil Union Act was one of the mechanisms advancing the transformation of queerness in post-1994 South Africa. A specific focus will be placed on the Act, and not on the concepts of

110 Wiredu (n 108) 56.

111 T Serequeberhan 'African philosophy as the practice of resistance' (2009) 4 Journal of Philosophy: A Cross Disciplinary Inquiry at 46.

112 Wiredu (n 108) 54; Serequeberhan (n 111) 49.

113 W Mignolo 'A manifesto' (2011) 26 Transmodernity at 49.

114 Gedro \& Mizzi (n 106) 447.

115 Van Marle \& Bonthuys (n 14) 22.

116 B Hooks Feminism is for everybody: Passionate politics (2000) 58.

117 Van Marle \& Bonthuys (n 14) 22.

118 Van Marle \& Bonthuys (n 14) 24. 
transformative constitutionalism and adjudication. This is due to the fact that these concepts dealt with the decriminalisation of queer identity and essentially set the foundation for transformation or decolonisation. ${ }^{119}$ As a result, the approach thereafter had to ensure the best outcomes for queer people and their identities.

Based on the context established in this essay, it can be asserted that the Civil Union Act never achieved sufficient transformation and decolonisation of queerness. First, the Act can be seen as a concession to colonialism because it incorporates the same christian-western values found in the Marriage Act. In addition to this, the inclusion of section 6 is a clear indication of the governments reluctancy to abandon homophobic and traditional beliefs. Second, the Act is set up in such a way that it is tailored towards individuals who identify as gay and lesbian. 120 Thirdly, the creation of a 'separate but equal' Act reinforces the harmful distinctions and differences between homosexual and heterosexual individuals. Lastly, the lack of cooperation between feminist and queer activists leads to isolationism and minimal advantages for each group. ${ }^{121}$

The set up and contents of the Act do not align with the principles in queer, feminist and decolonial theories. In order to successfully decolonise queerness and with specific regard to these theories, the Act needed to disidentify from colonial concepts perpetuated by religious and government institutions. Moreover, the Act needed to question the structure of identities and in some way disturb identities; not define them. ${ }^{122}$ Thus, the positionality of queerness and the universalist notion of queerness was never questioned. The inevitable conclusion is that: the Act did not achieve decolonisation of queerness because it assimilated to the western construct of marriage and it failed to deconstruct the ideology that harms so many queer individuals.

Apart from the above-mentioned criticisms, same-sex marriage legislation can be seen as problematic because it does not represent, nor does it extend to the complexities we see on the spectrum of identities. Thus, I can argue that it may not be for all queer people because it favours individuals who identify within the binary of gender and on the far ends (cis ends) of the spectrum of identity (it neglects individuals who show variations in identity). ${ }^{123}$ Legislation should avoid doing this because it runs the risk of equating queerness to

119 Refer back to pages $45-47$ of this Article (3.1 and 3.2 'Transformative constitutionalism' and 'Transformative adjudication').

120 TL Mccormick (n 102) https://theconversation.com/why-same-sex-marriage-isnot-the-ultimate-tool-for-queer-liberation-103702.

121 Bonthuys (n 21) 527.

122 Refer back to page 53-54 of this Article (4.1 'Queer, decolonial and feminist theories').

123 TL Mccormick (n 102) https://theconversation.com/why-same-sex-marriage-isnot-the-ultimate-tool-for-queer-liberation-103702. 
specific, isolated, LGBT-Q identities and their societally influenced gendered performances. ${ }^{124}$ Another approach that legislation should avoid taking is isolating the struggles and victories of marginalised groups. Race, gender and sexual orientation intersect to such a large degree that one cannot be preferentially treated over the other. ${ }^{125}$ The fight for gender and racial equality incorporated the fight for sexual orientation equality. Thus, legislation that focuses on singular identities and the prioritisation of one form of equality, is detrimental to all three movements because all three movements could benefit from each other. ${ }^{126}$ Feminist, decolonial and queer theories overlap with one another and they require a form of coalition activism that ensure the successful decolonisation of colonial constructs. ${ }^{127}$

Feminist, decolonial and queer theories aim to bring about reconstruction and decolonisation. They are the most effective tools that can be used to achieve this because they are identity based and they avoid all the harms that transformative law-making succumbs to.

\section{Conclusion}

In this essay I have investigated, criticised and re-contextualised the concept of queerness in South Africa. The current approach to queerness is transformative in nature but not necessarily 'queer'. I have demonstrated that there are shortfalls in the transformative mechanisms employed thus, an alternative is required. When dealing with queerness, you have to take into consideration the historical and identity based challenges of queer individuals. The transformative mechanisms considered the historical challenges of oppression but failed to incorporate the varying identities of queer individuals. Thus, my solution to this is queer theory and its intersections with decolonial and feminist theories. This approach considers all historical and identity challenges faced by the queer community and in doing so, decolonisation of queerness can occur which will implicitly incorporate the transformation of queerness as well.

Same-sex marriage is not the path to queer liberation as it merely transforms the institution it exists in - not the identities that exist in it. The underlying question then becomes: what is the queer concept of marriage? My answer is - nothing. I argue this because the most powerful opposition to marriage is not getting married at all. Queer individuals have placed an overvaluation on the concept of marriage and it has caused them to forget what it means to be 'queer'. We

124 Bonthuys (n 21) 527.

125 Giffney (n 1) 5; Van Marle \& Bonthuys (n 14) 23.

126 Van Marle \& Bonthuys (n 14) 23.

127 Refer back to page 53-54 of this Article (4.1 'Queer, decolonial and feminist theories'). 
need to reconstruct our identities and ensure that our concept of queerness is devoid of any western and colonial constructs that might limit us. Only then, can queerness truly be decolonised. 